\title{
Comparison between Bulgarian and Macedonian propolis: chemical composition and plant origin
}

\author{
Jasmina Petreska Stanoeva ${ }^{1}$, Marina Stefova ${ }^{1}$, Boryana Trusheva ${ }^{2}$, Milena Popova ${ }^{2}$, \\ Daniela Antonova $^{2}$, Vassya Bankova ${ }^{2 *}$ \\ ${ }^{1}$ Institute of Chemistry, Faculty of Natural Sciences and Mathematics, \\ Ss. Cyril and Methodius University, Arhimedova 5, 1000 Skopje, North Macedonia \\ ${ }^{2}$ Institute of Organic Chemistry with Centre of Phytochemistry, \\ Bulgarian Academy of Sciences, Acad. G. Bonchev str. Bl. 9, 1113 Sofia, Bulgaria
}

Received: July 2020; Accepted: September 2020

\begin{abstract}
Propolis is used as a constituent in over-the-counter preparations, food additives, cosmetics, etc. Bulgarian and Macedonian propolis samples were analyzed by gas chromatography - mass spectrometry (GC-MS) of ethanol extracts after silylation, in order to determine the presence of bioactive substances with antimicrobial and antioxidant activity and their chemical profiles were compared. Bulgarian and Macedonian propolis demonstrate very similar chemical profiles and belong to the Poplar type propolis, which has wellcharacterized qualitative composition and high content of bioactive substances. These results allow the standardization of Macedonian propolis to be approached on the basis of the recommendations by the International Honey Commission for poplar propolis.
\end{abstract}

Keywords: Bulgarian propolis, Macedonian propolis, GC-MS, chemical profiling

\section{Introduction}

North Macedonia and Bulgaria have a long history of production and use of bee products, dating back to the 1 Millennium BC. Propolis is one of the most popular bee products, used by traditional and modern medicine in prophylactics and treatments of numerous diseases. Propolis is collected by bees from tree excretions and possesses antibacterial, antifungal and antiviral properties and many other beneficial pharmacological activities (Sforcin and Bankova, 2014). It is one of the most popular home-made remedies in the Balkan countries (Wollenweber et al., 1990), but is also used as a constituent in over-the-counter preparations, food additives, health foods, as preservative in foods and cosmetics etc. (Bankova et al., 2016). The chemical composition of propolis is determined by the source plant and varies significantly in different geographic regions. The knowledge of the chemical composition, the presence of bioactive components and plant origin of propolis is a basic prerequisite for its chemical standardization (Bankova, 2005).

The aim of the present study is to characterize and compare the chemical composition of propolis from Bulgaria and North Macedonia, and to determine the presence of biologically active substances with antimicrobial and antioxidant activity, having the potential to improve human health. For this purpose, we used GC-MS, a well-established technique for chemical profiling of propolis (Bankova et al., 2019).

\footnotetext{
*bankova@orgchm.bas.bg
} 


\section{Material and methods}

\section{Propolis}

Propolis was supplied by beekeepers in July-August 2017, from the regions of Lovetch (BG-1), Elena (BG-2), and Strandzha Mountain (BG-3) in Bulgaria, and Vodno Mountain near Skopje (MK-1), Delchevo (MK-2), and Kriva Palanka (MK-3) in North Macedonia.

\section{Extraction and sample preparation}

Frozen propolis (freezer) was grated and $1 \mathrm{~g}$ was dissolved in $30 \mathrm{~mL} 70 \%$ ethanol in a $100 \mathrm{~mL}$ flask and left for $24 \mathrm{~h}$ at room temperature. The extract was filtered and the extraction was repeated. The two extracts were combined and evaporated to dryness. $5 \mathrm{mg}$ of the propolis dry extract was dissolved in $50 \mu \mathrm{L}$ of dry (water-free) pyridine, and $75 \mu \mathrm{L}$ of bis(trimethylsilyl)trifluoroacetamide (BSTFA) were added. The mixture was heated at $80^{\circ} \mathrm{C}$ for $20 \mathrm{~min}$ and analyzed by GC-MS.

\section{GC-MS analysis}

The silylated samples were analyzed by GC-MS with a Hewlett-Packard gas chromatograph 5890 series II Plus, linked to a Hewlett-Packard 5972 mass spectrometer system equipped with a $30 \mathrm{~m}$ long, $0.25 \mathrm{~mm}$ i.d. and 0.5 $\mu \mathrm{m}$ film thickness HP5-MS capillary column. The temperature was programmed from 60 to $300{ }^{\circ} \mathrm{C}$ at a rate of $5{ }^{\circ} \mathrm{C} / \mathrm{min}$, and a $10 \mathrm{~min}$ hold at $300{ }^{\circ} \mathrm{C}$. Helium was used as a carrier gas at a flow rate of $0.8 \mathrm{~mL} / \mathrm{min}$. The split ratio was $1: 10$, the injector temperature $280{ }^{\circ} \mathrm{C}$, the interface temperature $300{ }^{\circ} \mathrm{C}$ and the ionization voltage 70 $\mathrm{eV}$. Identification of the compounds was performed using comparison of mass spectra and retention times of reference compounds (21 compounds), and the rest was tentatively identified using their mass spectra and retention time analysis. The semi-quantification was carried out by internal normalization. The sum of individual areas of the compounds corresponds to $100 \%$ area.

\section{Statistical analysis}

Student's $t$-test was performed to evaluate the existence of significant differences between the means for the detected components of the studied samples $(p<0.05)$.

\section{Results and discussion}

Three Bulgarian and three Macedonian samples, collected from different regions of the respective countries were studied. Over 40 individual compounds in the studied samples (data not shown) were identified by GCMS. The chemical profiles of all six samples were very similar both qualitatively and quantitatively. These chemical profiles can be represented in a concise manner by the percentage of the main structural groups of chemical constituents (Table 1). The major groups of chemical constituents of propolis from both countries were flavonoid aglycones (most abundant: pinocembrin, chrysin, galangin), phenolic acids (most abundant: caffeic, coumaric, ferulic) and their esters (most abundant: benzyl caffeate, CAPE, pentenyl caffeates), aromatic acids (most aboundant: benzoic, cinnamic), sugars. The Student's $t$ test demonstrated that the observed differences in the mean values of content of groups of compounds were not significant (Table 1). In addition, the amounts of the most important individual compounds with pronounced antimicrobial and antioxidant activity (Ristivojević et al., 2015; Velazquez et al., 2007) in Macedonian and Bulgarian propolis were compared (Table 2). The mean values of the concentration of two flavonoids, chrysin and galangin, were somewhat higher in Macedonian samples, the difference being statistically significant $(p<0.05)$. For pinocembrin, CAPE and caffeic acid, there were no significant differences.

The chemical profiles obtained by GC-MS clearly indicated the origin of all samples from the buds of black poplar Populus nigra L. (Bankova et al, 1992; Greenaway et al., 1990). This proves that in both countries propolis is a typical poplar type European propolis. The observed differences are within the expected variations in the resin composition of the poplar buds, influenced by the specific ecological conditions at the place where the trees grow, the time of propolis collection by bees, as well as the genetic characteristics of the individual trees (Greenaway et al., 1990).

\section{Conclusion}

Bulgarian and Macedonian propolis demonstrate very similar chemical profiles and belong to the poplar type propolis, which has well-characterized qualitative composition and high content of biologically active substances with proven antibacterial, antiviral and antioxidant properties. These results allow the standardization of Macedonian propolis to be approached on the basis of the parameters recommended by the International Honey Commission for poplar type propolis (Bankova et al., 2019).

\section{Acknowledgments}

Partial financial support by Bilateral project between Macedonian Academy of Sciences and Arts and Bulgarian Academy of Sciences is gratefully acknowledged. 
Table 1. Chemical composition (compound groups, GC-MS, percentage of TIC) of propolis from North Macedonia and Bulgaria

\begin{tabular}{|c|c|c|c|c|c|c|c|c|}
\hline Compound class & MK-1 & MK-2 & MK-3 & $\begin{array}{c}\text { Mean value } \pm \mathrm{SD} \text {, } \\
\mathrm{MK}\end{array}$ & BG-1 & BG-2 & BG-3 & $\begin{array}{c}\text { Mean value } \pm \mathrm{SD} \text {, } \\
\mathrm{BG}\end{array}$ \\
\hline Phenolic acids & 7.0 & 4.8 & 6.8 & $6 \pm 1^{a}$ & 4.3 & 5.6 & 12.7 & $8 \pm 4^{\mathrm{a}}$ \\
\hline Aromatic acids & 4.9 & 0.4 & 0 & $2 \pm 2^{\mathrm{b}}$ & 0.1 & 0.1 & 4.4 & $2 \pm 2^{\mathrm{b}}$ \\
\hline Phenolic acid esters & 19.1 & 12.7 & 14.4 & $15 \pm 3^{c}$ & 16.0 & 12.5 & 14.4 & $14 \pm 2^{\mathrm{c}}$ \\
\hline Flavonoids & 57.3 & 55.2 & 56.3 & $56 \pm 1^{d}$ & 55.9 & 51.5 & 41.7 & $50 \pm 7^{\mathrm{d}}$ \\
\hline Sugars & 0.9 & 4.1 & 2.7 & $3 \pm 2^{\mathrm{e}}$ & 1.6 & 4.6 & 4.9 & $4 \pm 2^{\mathrm{e}}$ \\
\hline
\end{tabular}

Note: Different letters denote mean values that are statistically different. For mean values with the same letter, the difference between the means is not statistically significant

Table 2. Content of individual constituents in propolis (GC-MS, percentage of TIC) from North Macedonia and Bulgaria

\begin{tabular}{|c|c|c|c|c|c|c|c|c|}
\hline Component & MK-1 & MK-2 & MK-3 & $\begin{array}{c}\text { Mean value } \pm \mathrm{SD}, \\
\mathrm{MK}\end{array}$ & BG-1 & BG-2 & BG-3 & $\begin{array}{c}\text { Mean value } \pm \mathrm{SD}, \\
\mathrm{BG}\end{array}$ \\
\hline Caffeic acid & 1.6 & 2.0 & 2.5 & $2 \pm 0.4^{\mathrm{a}}$ & 2.2 & 1.7 & 2.3 & $2 \pm 0.3^{\mathrm{a}}$ \\
\hline Caffeic acid phenethyl esteer (CAPE) & 2.9 & 3.3 & 6.3 & $4.2 \pm 2^{\mathrm{b}}$ & 3.2 & 1.5 & 2.0 & $2.2 \pm 0.9^{\mathrm{b}}$ \\
\hline Pinocembrin & 10.8 & 7.4 & 6.2 & $8 \pm 2^{\mathrm{c}}$ & 8.5 & 4.8 & 6.2 & $6 \pm 2^{\mathrm{c}}$ \\
\hline Chrysin & 8.8 & 11.5 & 9.4 & $10 \pm 1^{\mathrm{d}}$ & 8.2 & 7.2 & 7.0 & $7.5 \pm 0.6^{\mathrm{e}}$ \\
\hline Galangin & 9.2 & 6.7 & 8.7 & $8 \pm 1^{\mathrm{f}}$ & 6.6 & 5.3 & 5.1 & $5.7 \pm 0.8^{\mathrm{g}}$ \\
\hline
\end{tabular}

Note: Different letters denote mean values that are statistically different. For mean values with the same letter, the difference between

the means is not statistically significant 


\section{References}

Bankova, V., 2005. Chemical diversity of propolis and the problem of standardization. J. Ethnopharmacol. 100, 114 117. Available at: https://doi.org/10.1016/j.jep.2005.05.004.

Bankova, V., Bertelli, D., Borba, R., Conti, B.J., da Silva Cunha, I.B., Danert, C., Eberlin, M.N., Falcão, S.I., Isla, M.I., Nieva Moreno, M.I., Papotti, G., Popova, M., Basso Santiago, K., Salas, A., Frankland Sawaya, A.C.H., Schwab, N.V, Sforcin, J.M., Simone-Finstrom, M., Spivak, M., Trusheva, B., Vilas-Boas, M., Wilson, M., Zampini, C., 2019. Standard methods for Apis mellifera propolis research. J. Apicult. Res. 58, 1-49. Available at: https://doi.org/10.1080/00218839.2016.1222661.

Bankova, V., Dyulgerov, A., Popov, S., Evstatieva, L., Kuleva, L., Pureb, O., Zamjansan, Z., 1992. Propolis produced in Bulgaria and Mongolia: phenolic compounds and plant origin. Apidologie 23, 79 - 85. Available at: https://doi.org/10.1051/apido:19920109.

Bankova, V. Popova, M., Trusheva, B., 2016. New emerging fields of application of propolis. Maced. J. Chem. Chem. Eng. 35, 1-11. DOI: http://dx.doi.org/10.20450/mjcce.2016.864.

Greenaway, W., Scaysbrook, T., Whatley, F. R., 1990. The composition and plant origins of propolis: a report of work at Oxford. Bee world 71, 107-118. Available at: https://doi.org/10.1080/0005772X.1990.11099047.

Ristivojević, P., Trifković, J., Andrić, F., Milojković-Opsenica, D., 2015. Poplar-type propolis: chemical composition, botanical origin and biological activity. Nat. Prod. Commun. 10, 1869 - 1876. Available at: https://doi.org/10.1177/1934578X1501001117.

Sforcin, J.M., Bankova, V., 2011. Propolis: Is there a potential for the development of new drugs? J. Ethnopharmacol. 133, 253-260.

Velazquez, C., Navarro, M., Acosta, A., Angulo, A., Dominguez, Z., Robles, R., Robles-Zepeda, R., Lugo, E., Goycoolea, F.M., Velazquez, E.F., Astiazaran, H., Hernandes, J., 2007. Antibacterial and free-radical scavenging activities of Sonoran propolis. J. Appl. Microbiol. 103, 1747-1756. Available at: https://doi.org/10.1111/j.1365-2672.2007.03409.x.

Wollenweber, E., Hausen, B.M., Greenaway W., 1990. Phenolic constituents and sensitizing properties of propolis, poplar balsam and balsam of Peru. Bull. Groupe Polyphenols 15, 112-120.

\title{
Споредба помеѓу македонски и бугарски прополис: хемиски состав и растително потекло
}

\author{
Јасмина Петреска Станоева ${ }^{1}$, Марина Стефова ${ }^{1}$, Борјана Трушева ${ }^{2}$, \\ Милена Попова ${ }^{2}$, Даниела Антонова ${ }^{2}$, Васја Банкова ${ }^{2} *$ \\ ${ }^{1}$ Институт за хемија, Природно-математички факултет, \\ Универзитет „, Св. Кирил и Методиј”, Архимедова 5, 1000 Скопје, Северна Македонија \\ ${ }^{2}$ Институт за органска хемија и иентар за фитохемија, Бугарска академија на \\ науките, ул. Акад. Г. Бончев блок 9, 1113 Софија, Бугаријау
}

Клучни зборови: бугарски прополис, македонски прополис, ГЦ-МС, хемиско профилирање

Прополисот најчесто е присутен како состојка во препаратите кои се издаваат без рецепт, додатоците во исхрана, козметичките препарати, итн. Примероците од прополис со потекло од Бугарија и Македонија беа анализирани со гасна хроматографија - масена спектрометрија (ГЦ-МС) на екстракти од етанол по нивна силилација. Главната цел беше определување на присуството на биоактивни супстанции со антимикробна и антиоксидативна активност како и споредба на нивните хемиски профили. Резултатите од испитувањата покажаа дека прополисот со потекло од Бугарија и Македонија имаат многу слични хемиски профили и истите припаѓаат на прополисот од топола, кој има добро карактеризиран квалитативен состав и голема содржина на биоактивни супстанции. Добиените резултати може да бидат искористени за стандардизација на македонскиот прополис согласно препораките на Меѓународната комисија за мед од прополис од топола. 